\title{
ECOLOGICAL AND ECONOMIC ASPECTS OF THE APPLICATION OF SEWAGE SLUDGE IN ENERGETIC PLANT PLANTATIONS - A SWOT ANALYSIS
}

\author{
Marta WÓJCIK ${ }^{1}$, Feliks STACHOWICZ, Adam MASŁOŃ \\ Rzeszow University of Technology, Rzeszów, Poland
}

\begin{abstract}
Sewage sludge management in Poland is a relatively new field of waste management called "in statu nascendi", the standards of which have not been recognized yet. It also requires the implementation of new solutions in the field of sewage sludge. So far, the most popular method of sewage sludge utilization has been landfill disposal. In line with the restriction placed on landfill waste with a calorific value above $6 \mathrm{MJ} / \mathrm{kg}$ introduced on 1 January 2016, agricultural use and thermal methods are particularly applied.

Municipal sewage sludge may be successfully used in the cultivation of energetic plant plantations. The aforementioned waste could be treated as an alternative to traditional mineral fertilizers, which in turn might successfully provide valuable nutrients for plants. This paper illustrates the SWOT analysis (Strengths, Weaknesses, Opportunities, and Threats) associated with the use of sewage sludge from Świlcza-Kamyszyn WTTP (Podkarpackie Province, Poland) for agricultural purposes. This analysis could be useful in evaluating the utility of sewage sludge in perennial plant plantations in order to determine the appropriate waste management strategies.
\end{abstract}

Keywords: sewage sludge, SWOT analysis, sewage sludge management, energetic plants

\footnotetext{
${ }^{1}$ Corresponding author: Rzeszow University of Technology, Faculty of Mechanical Engineering and Aeronautics, Department of Materials Forming and Processing, Powstańców Warszawy Av. 8, 35-959 Rzeszów, Poland, e-mail: m.wojcik@ prz.edu.pl, tel. +48178651507
} 


\section{INTRODUCTION}

Recently there has been a growth of public awareness concerning the environmental risks resulting from inappropriate sewage sludge management. This is particularly evident in increasingly strict regulations concerning sludge in the European Union and in member states, including Poland. As a problematic waste product, sewage sludge requires continuous searching for more advanced and effective methods of utilization.

Currently, three dominant sewage sludge utilization methods can be identified in Poland: disposal in a landfill, natural use, and combustion, among which the most popular is disposal in a landfill [11]. In line with the restriction placed on landfill waste with a calorific value above $6 \mathrm{MJ} / \mathrm{kg}$ which was introduced on 1 January 2016 [14], the most economically and environmentally-friendly method of sewage sludge utilization is in agricultural use. The use of sewage sludge in agriculture or for reclamation is also characterized by the lowest costs, ranging from $300 \div 400 \mathrm{PLN}$ for $1 \mathrm{Mg}$ sludge [5]. In contrast, combustion and cocombustion of sewage sludge is more expensive, even fivefold [16]. The agricultural method is particularly recommended for sewage sludge from small and medium-sized treatment plants. Agricultural and other natural ways of sludge management are legally permitted if they do not exceed permissible concentrations of heavy metals and biogenic compounds, as stated in the Regulation on Urban Sewage Sludge of 15 February 2015 [13]. For this reason, the application of sewage sludge in agriculture could necessitate detailed analysis of physical and chemical properties of sludge.

Sewage sludge might be successfully used in the cultivation of energetic plant plantations. Despite its many advantages, such application of sewage sludge is currently rarely used. This phenomenon might simply be the result of insufficient knowledge amongst farmers with respect to fertilization using sewage sludge. Sewage sludge utilization in perennial plant plantations allows the retention of the turnover of nutrients, closing the circuit elements in the local ecosystem. Moreover, chemical compounds contained in sewage sludge are excluded from the human food chain. Particular features of energy plant construction enable them to take nutrients contained in sewage sludge without environmental contamination. Additionally, energy plants have a high demand for nutrients and are characterized by a large absorbent surface [15]. Energy plant plantations require artificial surface fertilization using mineral fertilizers for proper growth. Municipal sewage sludge should be treated as an alternative to traditional mineral fertilizers, which in turn might successfully provide valuable nutrients for plants and could substitute popular fertilizers. According 
to Grzybek [4], the costs of fertilizing constitute up to $40 \%$ of the entire costs of perennial plant plantations.

Due to the heterogenic structure, agricultural use of sewage sludge depends on many internal and external factors, for example (Fig. 1):

- legal aspects at both local and national level,

- social circumstances associated with public acceptance concerning the use of sewage sludge in agricultural practices,

- geographical requirements associated with hydrogeological conditions and topography,

- requirements of logistics which are determined by the transport and raising of sludge.

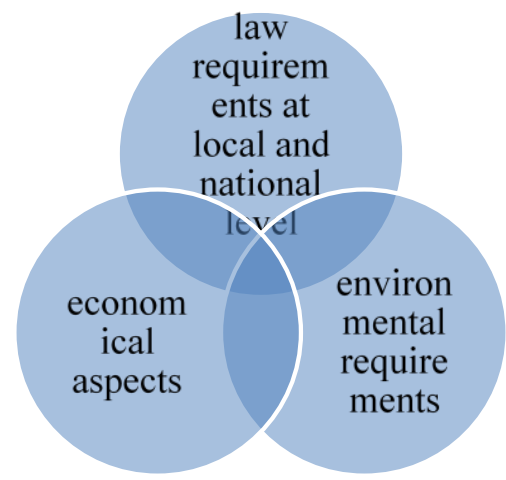

Fig. 1. The factors influencing the agricultural use of sewage sludge

This article presents the SWOT analysis (Strengths, Weaknesses, Opportunities, and Threats) associated with the use of sewage sludge in perennial plant plantations. All points of the analysis were described and compared. The indication of advantages and opportunities might contribute to the popularization of agricultural use of sewage sludge in energetic plant plantations.

\section{METHODOLOGY}

While considering the problems associated with proper utilization of sewage sludge, the preparation of a SWOT analysis becomes essential from an environmental and economic point of view. In national literature, there is currently no SWOT analysis in terms of the application of sewage sludge in perennial plant plantations. The aforementioned analysis could, therefore, evaluate the utility of sewage sludge in perennial plant plantations in order to indicate the appropriate waste management strategies. 
The SWOT analysis was prepared on the basis of literature review and experimental tests carried out by many researchers. Environmental, social, and legal requirements were considered in the SWOT analysis according to the scheme below (Fig. 2).

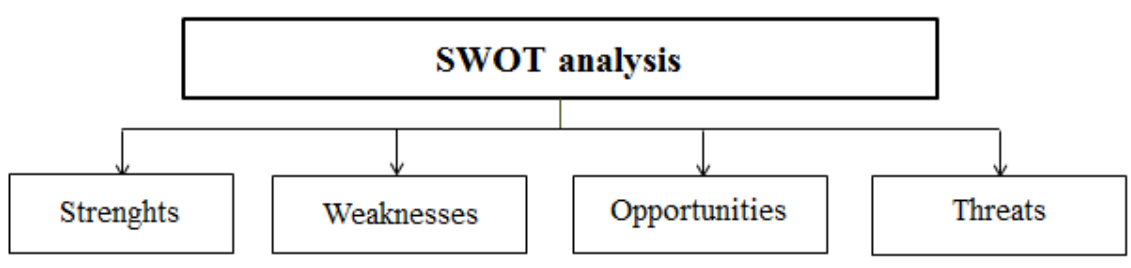

Fig. 2. The SWOT diagram [12]

\section{RESULTS AND DISCUSSION}

With the development of the sewerage system and the tightening of regulation of waste management, the amount of produced sewage sludge is systematically growing. As sewage sludge treatment is a costly process, it becomes necessary to develop sludge utilization methods that bring maximum advantages from an economic point of view.

For local and municipal wastewater treatment plants, the agricultural use of sewage sludge is the best solution. An example of such a treatment plant is WTTP in Świlcza-Kamyszyn (Podkarpackie Province, Poland). Due to the fact, that sewage sludge derived from Swilcza WTTP does not exceed limits associated with the content of heavy metals, sludge could be applied as a fertilizer in perennial plant plantations. The use in agriculture, forestry or for restoring degraded lands is not a widely applied practice in Europe but is studied in research projects and extensively debated in scientific publications [12]. This method also enables partial financial recovery.

The SWOT analysis based on the use of sewage sludge in energetic plant plantations, exemplified by the above-mentioned treatment plant, is shown in Table 1. As the SWOT analysis demonstrates, the application of sewage sludge from Świlcza WTTP in perennial plant plantations has many advantages, disadvantages, opportunities, and threats. All benefits and threats are described in the following points below.

\subsection{Strengths}

Sewage sludge is waste that is both complex and problematic in nature and, therefore, must be utilized in accordance with environmental, legal, and 
ecological requirements. In keeping with the waste management agreement, as much waste should be recycled as possible. Because sewage sludge is the kind of waste for which prevention is currently impossible, it is necessary to ensure reuse and recycling in line with environmental protection principles. For this reason, the application of sewage sludge in energetic plant plantations enables its proper management while leveraging its fertilizing properties. Additionally, sewage sludge is inexpensive and easily-obtained which is advantageous from an economic point of view.

Table 1. SWOT analysis for the application of sewage sludge as a fertilizer

\begin{tabular}{|c|c|}
\hline STRENGTHS & WEAKNESSES \\
\hline 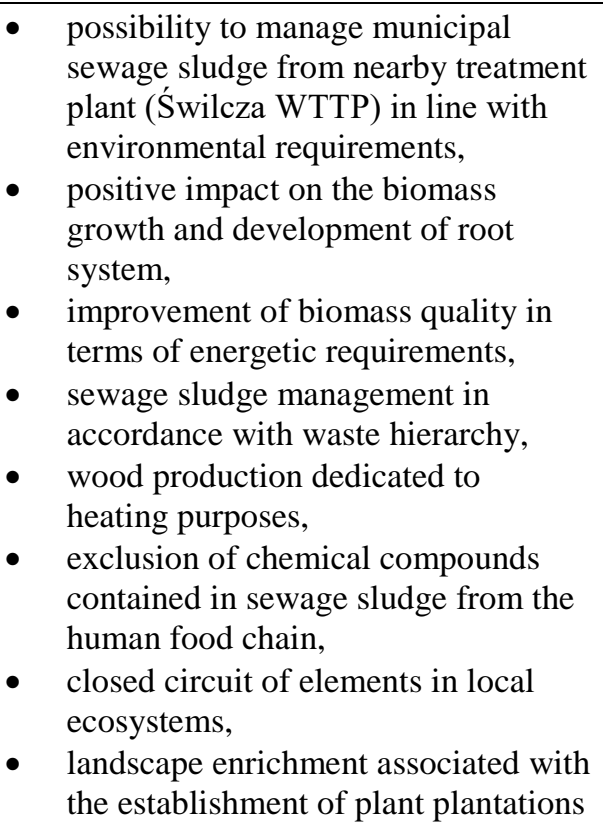 & 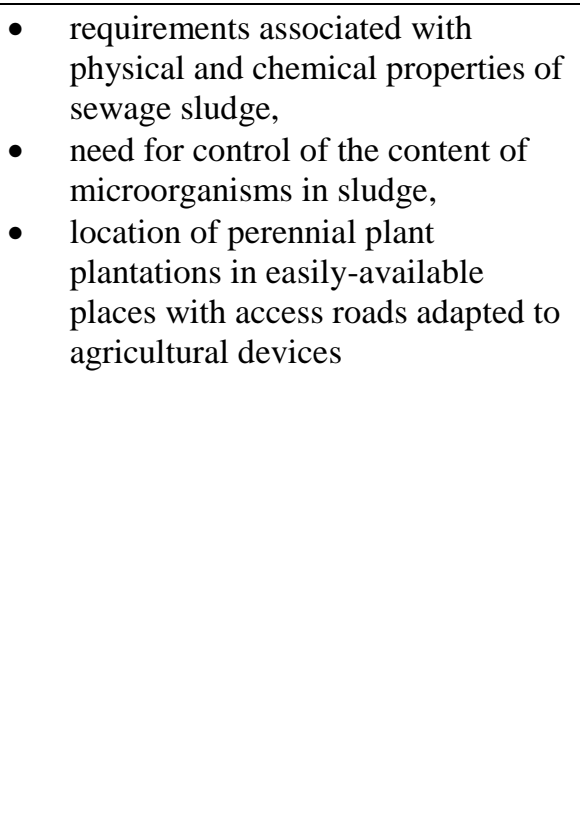 \\
\hline OPPORTUNITIES & THREATS \\
\hline $\begin{array}{l}\text { - } \\
\text { - } \quad \text { devil quality improvement, } \\
\text { market, } \\
\text { - } \quad \text { soil conservation against erosion, } \\
\text { - } \quad \text { deplacement of traditional fertilizing, } \\
\text { - } \quad \text { perennial plant plantations, } \\
\text { - } \quad \text { reclamating new jobs, } \\
\text { recon of degraded lands. }\end{array}$ & $\begin{array}{l}\text { - } \text { odor nuisance, } \\
\text { bioaerosols forming, } \\
\text { - } \text { soil acidification and the increase of } \\
\text { metals accessibility, } \\
\text { requirements concerning } \\
\text { fertilization with use of sewage } \\
\text { sludge }\end{array}$ \\
\hline
\end{tabular}


Sewage sludge is a rich source of nutrients which encourages its use as a fertilizer for plants. Due to its similar chemical composition to humus, sewage sludge might be treated as an organic fertilizer. Tests carried out by numerous researchers have proved the positive impact of sewage sludge on the growth of energetic plants. Lisowski et al. [10] showed that the use of sewage sludge as an organic fertilizer increased Miscanthus yield by approximately $80 \%$ in comparison with plants without fertilization. Augustynowicz et al. [1] also proved that the application of sewage sludge influenced the efficiency of photosynthesis of Virginia mallow. Referring to the results obtained by Szurkowski [17], fertilization of energetic willow Salix viminalis by means of sewage sludge resulted in biomass growth at a level of $60 \%$. It is also worth highlighting that the use of sewage sludge as a fertilizer improves a plant's immunity to negative external factors and influences the development of the root system. According to Rosikon [15], energetic plants which grow in soil with sewage sludge form more roots than unfertilized plants. These facts confirm the advisability of the application of sewage sludge in perennial plant plantations.

Properly prepared sewage sludge might be successfully used in the cultivation of energy plant plantations. This method enables retention of the turnover of nutrients which closes the circuit elements in the local ecosystem. Due to the fact that biomass obtained from energetic plant plantations can be used for heating purposes, chemical compounds contained in sewage sludge are excluded from the human food chain. Particular features of an energy plant's construction allow it to absorb nutrients contained in sewage sludge without environmental contamination.

Biomass obtained from energetic plants is characterized by a different quality and chemical composition which is why energetic plant plantations are not relatively popular in Poland. According to Janiszewska [7], approximately 450 thousand hectares might be used for cultivation of perennial plant plantations, whereas currently, the aforementioned plantations account for approximately 10.2 thousand hectares. Fertilizing with the use of sewage sludge influences the quality and quantity of biomass in terms of the energetic value. Kacprzak et al. [8] have shown that the fertilizing of Phalaris arundinacea with the use of sewage sludge has a positive impact on its energetic value. It is worth mentioning that the improvement of biomass energetic efficiency is one of the priorities of the European Union in compliance with the requirements of the EU climate and energy package ( $3 \times 20 \%)$.

Additionally, the establishment of perennial plant plantations has a positive impact on local landscape and biodiversity. The influence of energetic plants on the environment is shown in Table 2. Energetic plant plantations stimulate the 
development of rural areas, creating jobs and reducing greenhouse gases emissions.

\subsection{Weaknesses}

An important factor which limits the application of sewage sludge as a fertilizer is the sanitary safety of waste obtained in the final stage of sludge treatment. Agricultural utilization of sewage sludge is legally permitted if it does not exceed permissible concentrations of heavy metals and biogenic compounds, as stated in the Regulation on Urban Sewage Sludge of 15 February 2015. Excessive concentrations of heavy metals in sewage sludge disturb the balance between various nutrients in soil. For agricultural purposes, sewage sludge does not contain Salmonella and intestinal parasites. For this reason, sewage sludge used in perennial plant plantations has to be biochemically and microbiologically stable, which is associated with the need to perform expensive laboratory tests. In view of the fact that approximately $3 / 4$ of the amount of sewage sludge produced does not exceed the limits in terms of heavy metals, sewage sludge might be applied as a valuable fertilizer without risk to the environment [18].

Table 2. Influence of selected energetic plants on the environment

\begin{tabular}{|l|c|c|}
\hline \multirow{2}{*}{ Influence on the environment } & \multicolumn{2}{|c|}{ Type of plant } \\
\cline { 2 - 3 } & Salix viminalis & Miscanthus \\
\hline carbon sequestration & + & + \\
\hline nitrogen exchange/erosion & +++ & ++ \\
\hline landscape & ++ & ++ \\
\hline biodiversity of birds & ++ & no effects \\
\hline biodiversity of plants & ++ & ++ \\
\hline biodiversity of invertebrates & ++ & + \\
\hline biodiversity of mammals & + & + \\
\hline hydrological conditions & no effects & no effects \\
\hline energy and carbon balance & +++ & +++ \\
\hline
\end{tabular}

+ - small influence

++- medium influence

+++ - significant influence

The other restriction on the application of sewage sludge in energetic plant plantations is ensuring a convenient location for the plantation. Fertilization with the use of sewage sludge requires specialized agricultural devices. For this reason, it is necessary to locate plantations in easily-available places which are assured access; in order to fertilize plantations with the use of agricultural devices, it is necessary to build three-meter-wide roads. 


\subsection{Opportunities}

Sewage sludge is a rich source of nutrients for plants which confirms their application as a fertilizer. The chemical composition of sewage sludge is comparable with humus and, for this reason, agricultural utilization of this waste is justified.

Sewage sludge influences the content of assimilable nitrogen and phosphorus in the soil. According to Jama [6], $10 \mathrm{~cm}^{3}$ of sewage sludge delivers approximately: $30 \mathrm{~kg}$ of nitrogen, $80 \mathrm{~kg}$ of phosphorus, $15 \mathrm{~kg}$ of potassium, and $15 \mathrm{~kg}$ of $\mathrm{CaO}$. Additionally, the application of sewage sludge improves the soil structure and increases the degree of infiltration. Gostomczyk [3] also proved the positive impact of sewage sludge on the number of bacteria in soil. Soil contamination caused by the addition of sewage sludge was not stated. Additionally, energetic plants are rooted and grown quickly. Therefore, such plantations provided better protection against erosion.

In Poland, the majority of perennial plant plantations are established in remotes areas with low humus and nutrient content for plants. According to Szurkowski [17], willow trees require approximately $60 \mathrm{~kg}$ nitrogen, $8 \mathrm{~kg}$ phosphorus, and $43 \mathrm{~kg}$ potassium in order to achieve a yield of 10 tons d.m./ha. An acceptable yield might be achieved by intensive fertilizing which contributes to the high maintenance costs of a plantation, however, it is estimated that fertilization's costs of perennial plant plantations constitute approximately $40 \%$ of total costs. The alternative solution might, therefore, be properly prepared sewage sludge. Due to failures in agricultural practices, agricultural lands are often treated as wastelands. After years of neglect, the return to cultivation is very difficult or even impossible. The application of sewage sludge could recreate soil conditions and restore the balance between nutrients.

Energy consumption is one of the main factors which stimulate social and economic development. For this reason, energy demands are systematically growing and, so far, these energy demands have been covered by fossil fuels such as coal. The development of the renewable energy market requires new environmentally-friendly and clean energy sources. Biomass might well be considered such a source. According to Faber et al. [2], the share of forest biomass in energy production is systematically increasing. It serves to strengthen the position of energetic plants in the global energy market and helps popularize renewable energy in the final stages of energy production. The progress of the renewable energy market also allows the creation of new jobs and encourages rural development. However, energy derived from energetic plants is profitable only in the local market. Long distance transport of biomass 
might generate higher costs and decrease the profitability of the whole investment.

\subsection{Threats}

Before the application of sewage sludge in perennial plant plantations, it is necessary to consider potential threats to the environment. One of the main disadvantages of sewage sludge utilization is the possibility of releasing strong odors during the spreading of sludge onto the soil. It is worth noting, however, that energetic plant plantations are located far from human habitats. Owing to this, odor nuisance and bioaerosols are not considered so burdensome for the local population. For this reason, sewage sludge might be used as a fertilizer before the establishment of a perennial plant plantation.

The use of sewage sludge might also cause soil acidification and it is possible that the addition of sewage sludge could increase bioavailability of metals. Research carried out by Kalembasa and Malinowska [9] has shown precipitation that fertilization by means of sewage sludge results in higher of zinc and cadmium by plants. It has also been confirmed that some metals, for example, iron, manganese, and lithium, are accumulated in leaves to a greater extent, and molybdenum and strontium in plant stalks. The intensive precipitation of heavy metals from soil and their accumulation in plants contribute to new technical and environmental problems associated with the utilization of sewage sludge combustion by-products.

\section{CONCLUSIONS}

This paper presents the SWOT analysis of the application of sewage sludge in energetic plant plantations. The aforementioned analysis includes economic, environmental, legal, and social aspects. The whole analysis includes both advantages and disadvantages associated with the cultivation of energetic plants with the use of sewage sludge.

The most economically and environmentally-friendly method of sewage sludge utilization is its agricultural use. The sewage sludge utilization methods discussed herein are advantageous both for farmers and producers of sludge. Properly prepared municipal sewage sludge provides valuable nutrients improving plant growth and might, therefore, be a viable substitute for popular fertilizers.

Sewage sludge could be successfully used in the cultivation of energy plant plantations. The above-described method enables retention of the turnover of nutrients, which closes the circuit elements in the local ecosystem. Moreover, chemical compounds contained in sewage sludge are excluded from the human food chain. For this reason, the negative influence of sewage sludge on human 
health is reduced significantly. The main disadvantage of the aforementioned application of sewage sludge is the possibility of heavy metals accumulating in plants and the risk of soil acidification.

Agricultural sewage sludge utilization is a compromise between the advantages and disadvantages. The presented SWOT analysis could contribute to the popularization of this method. Due to its specific properties, sewage sludge may be successfully used in the cultivation of energy plant plantations. Consequently, it might be possible to achieve a $20 \%$ share of renewable energy in final energy production, in compliance with the requirements of the EU climate and energy package ( $3 \times 20 \%$ ) [16]. In conclusion, the use of sewage sludge in perennial plant plantations is a method for which the advantages outweigh the disadvantages.

\section{REFERENCES}

1. Augustynowicz J., Pietkiewicz S., Kalaji M. H., Russel S.: Wptyw nawożenia osadem ściekowym na wybrane parametry biologii gleby oraz wydajności aparatu fotosyntetycznego ślazowca pensylwańskiego (Sida Hermaphrodita (L.) Rusby). Nauka Przyroda Technologie, 6, 4 (2010), 1-11.

2. Faber A., Kuś J., Matyka M.: Uprawa roślin na potrzeby energetyki. Warszawa, PKPP Lewiatan 2009.

3. Gostomczyk K.: Osady ściekowe alternatywa dla nawozów sztucznych $w$ uprawie wierzby. Zeszyty Naukowe Wydziału Nauk Ekonomicznych Politechniki Koszalińskiej, 18 (2014), 35-46.

4. Grzybek A.: Prognoza wykorzystania odnawialnych źródeł energii w sektorze rolnym na tle przemian. Rozwój energii odnawialnej na Pomorzu Zachodnim. edit. Piotr Lewandowski and Władysław Nowak. Hogben 2004, 211-218.

5. Henclik A., Kulczycka J., Gorazda K., Wzorek Z.: Uwarunkowania gospodarki osadami ściekowymi w Polsce i Niemczech. Inżynieria i Ochrona Środowiska, 17, 2, (2014), 185-197.

6. Jama A.: Wpływ komunalnych osadów ściekowych na plonowanie i rozwój wybranych klonów wierzby krzaczastej (S. viminalis L.). PhD Thesis, Wrocław 2011.

7. Janiszewska D.A.: Potencjat energetyczny upraw wierzby na gruntach marginalnych $w$ Polsce. Zeszyty Naukowe Wydziału Nauk Ekonomicznych Politechniki Koszalińskiej, 18 (2014), 47-56.

8. Kacprzak M., Rosikoń K.: The energetic value of selected plants growing on degraded soil fertilized by sewage sludge. Archivum Combustionis, 32, 3-4 (2012), 123-129. 
9. Kalembasa D., Malinowska E.: Wptyw dawek osadu ściekowego na plon biomasy trawy Miscanthus sacchariflorus (Maxim. Hack.), zawartość siarki oraz wartość energetyczną. Zeszyty Problemowe Postępów Nauk Rolniczych, 533 (2008), 173-179.

10. Lisowski J.: Wplyw nawożenia osadami na plon miskanta (Miscanthus giganteus). Fragmenta Agronomica, 27, 4 (2010), 94-101.

11. Niemiec W., Wójcik M.: Możliwości wykorzystania komunalnych osadów ściekowych $w$ wybranych oczyszczalniach. OW PRz, Zeszyty naukowe Mechanika, 87, 4 (2015), 339-347.

12. Răducanu D., Goldan E., Rati I.V., Olugu S.H.V., Lazar I.: The use of sewage sludge in agriculture: a SWOT analysis. Studii şi Cercetări. Biologie. Universitatea"Vasile Alecsandri” din Bacău, 24, 1 (2015), 18-26.

13. Regulation of the Minister of Environment of February 6, 2015 on municipal sewage sludge (Journal of Laws 2015, item 257).

14. Regulation of the Minister of Economy of July 16, 2015 on Acceptance of Waste for landfill (Journal of Law 2015 item 1277).

15. Rosikon K.: Osady ściekowe $w$ nawożeniu wybranych roślin energetycznych. Inżynieria i Ochrona Środowiska, 17, 2, (2014), 339-348.

16. Stachowicz F., Trzepieciński T., Wójcik M., Masłoń A., Niemiec W., Piech A.: Agricultural utilisation of municipal sludge in willow plantation. E3S Web of Conferences, 10 (2016), 1-6.

17. Szurkowski S., Tworkowski J., Stolarski M.: Wierzba energetyczna. Krakow, Plantpress 2004.

18. Wójcik M., Stachowicz F., Masłoń A.: Techniczne aspekty przyrodniczego stosowania osadów ściekowych. Forum Eksploatatora, 87, 6 (2016), 36-43.

\section{EKOLOGICZNO-EKONOMICZNE ASPEKTY ZASTOSOWANIA OSADÓW ŚCIEKOWYCH NA PLANTACJACH ROŚLIN ENERGETYCZNYCH - ANALIZA SWOT}

\section{Streszczenie}

Gospodarka osadami ściekowymi w Polsce jest stosunkowo nową dziedziną gospodarki odpadami określaną jako „in statu nascendi”, która nie doczekała się w kraju uznanych standardów i wymaga wdrażania nowych rozwiązań. Dotychczas, dominującą metodą zagospodarowania osadów ściekowych było ich składowanie. Wobec obowiązującego od 1 stycznia 2016 r. zakazu składowania odpadów o wartości opałowej powyżej $6 \mathrm{MJ} / \mathrm{kg}$, dominujący udział wykazują metody termiczne oraz przyrodnicze i rolnicze zagospodarowanie. 
Osady ściekowe mogą znaleźć zastosowanie w nawożeniu upraw roślin energetycznych. Wspomniany odpad może stanowić substytut dla popularnych nawozów mineralnych, dostarczając cennych składników pokarmowych dla roślin. Artykuł przedstawia analizę SWOT dotyczącą zagospodarowania osadów ściekowych w celach przyrodniczych w oczyszczalni ścieków w Świlczy-Kamyszyn w województwie podkarpackim. Przedstawiona analiza pozwala ocenić przydatność osadów w nawożeniu plantacji roślin energetycznych, co pozwala wskazać prawidłowe strategie w gospodarce odpadami.

Słowa kluczowe: osady ściekowe, analiza SWOT, gospodarka osadami ściekowymi, rośliny energetyczne

Editor received the manuscript: 22.06.2017 